\title{
Negotiation of Legitimacy of Witch-Finders in Lusaka
}

\author{
KATEŘINA MILDNEROVÁ \\ Department of Sociology, Andragogy and Cultural Anthropology \\ Palacký University, Olomouc, Czech Republic \\ katerina.mildnerova@upol.cz
}

\begin{abstract}
The article aims at legal and illegal activities of Lusaka's traditional healers within the system of traditional medicine which is primarily anchored in the constitution of traditional healers' associations. It primarily focuses on witch-finders, whose social status, professional position and authority is constantly negotiated within the formal and informal sector of traditional medicine. Since the late 1990s, the quest for services of traditional healers specialised in witch-finding has gained popularity, particularly amongst the impoverished Lusaka compound-dwellers. Due to the increasing public violence against those denoted as witches, the activities of witch-finders were officially banned by the Witchcraft Act in 1995 and this profession is not officially recognised by the Constitution of Traditional Health Practitioners Association of Zambia (THAPAZ). In spite of the prohibition, there remain many witch-finders in Lusaka who practise witch-finding secretly, in order not to commit an offence they do not openly denounce the name of an alleged witch. Their authority and credibility is threatened by many "official" as well as "unofficial" competitors in the city and it must be constantly reaffirmed and negotiated by introducing innovations. The ability to keep clients and to gain a good reputation thus depends on the originality of their diagnostic and therapeutic procedures. At the same time witch-finders must counter diverse obstacles and uncertainties resulting from their illegal status within the sector of traditional medicine. The author analyses tactics that Lusaka's witch-finders have developed and employed to negotiate their social status, credibility and authority visà-vis the competition from the "official" traditional healers.
\end{abstract}


KEY WORDS: witch-finder; Lusaka; traditional medicine; formal and informal sector; healers 'associations; negotiation; credibility; authority; tactics

\section{Introduction}

The article draws on ethnographic data gained during the long-term fieldwork in Lusaka, the capital of Zambia. ${ }^{1}$ It focuses on legal and illegal activities of traditional healers (ng'anga) ${ }^{2}$ within the system of traditional medicine which is primarily anchored in the constitution of traditional healers' associations. It analyses diverse tactics that witchfinders employ to negotiate their legitimacy ${ }^{3}$ and credibility vis-à-vis the competition from the "official" traditional healers.

Witch-finder as a category of a healer is not officially recognised by any of existing traditional healers' association in Zambia and their activities are thus officially banned by their constitutions. Detection and accusation by naming the alleged witches is considered as an offence not only against the constitutions of traditional healers' associations but also against the law, in particular the Penal Code from 1995 that treats this issue in the chapter 90 called the Witchcraft Act.

In spite of these prohibitions there are many witch-finders in Lusaka practicing a detection of witches by means of divination (through "magical mirrors"), house and body cleansing off witchcraft objects, the protection against witches, healing diseases believed to be caused by witchcraft. Some of witch-finders also travel around the country to cleanse

1 During the fieldwork carried out between 2008-2009 and in 2013, the research techniques of semi-structured interview and participant observation of rituals and divination and healing séances were used. I interviewed 20 traditional healers, from which 8 were witch-finders. All names of the respondents used in the text are pseudonyms. The term Doctor (Dr.) in front of the name of traditional healers does not refer to an academic title but to a title of honour.

$2 \quad \mathrm{Ng}$ 'anga singular, ban'ganga plural in chiNyanja language.

3 Questions of legitimacy are distinct from questions of legality. Legality may be used as an argument for legitimation, but the connection is not necessary. Individuals' views about the legitimacy of rules may in practice either support or undermine the existing social order. Legitimacy, in this sense, is not an inherently conservative concept. Legitimacy, in my view, is socially constructed and it is primarily based on social consensus. In the process of the legitimization of traditional healers who evidently stay outside the legality (law), the belief in sacredness of cultural traditions transmitted from generation to generation plays an important role. 
villages off witchcraft at request of local chiefs. Their services are largely sought-out by the local population both in towns and villages as trust in western medicine is generally weak and certain unexplainable or incomprehensible diseases are locally conceptualised as matenda yakubantu (disease from people, i.e. witchcraft).

The majority of witch-finders hide their activities under the Competence Certificate as herbalists, diviners or spiritual healers issued by divers Zambian traditional healers' associations. Their profession, authority and social status is constantly threatened by representatives of diverse African Christian Independent churches, in particular the Pentecostal ones, who declare to fight against witchcraft, whereas they make no difference between witchcraft and traditional medicine. There are also Zambian media (TV and newspapers) involved in this "demonization campaign" against witch-finders pejoratively called "witch-doctors" who are presented as false healers, dangerous individual who may bewitch their clients to become rich. Finally, witch-finders in Lusaka must also constantly reaffirm and negotiate their position vis-à-vis increasing competition of those official traditional healers in the city.

My paper focuses on two main questions:

1) Which tactics do Lusaka's witch-finders employ to make them survive in the city, i.e. to carry out their job without being revealed and at the same time to compete with other official healers in city?

2) Which tactics do they employ to attract and keep their clients, to ensure a good reputation and legitimize their work in spite of the official barriers?

\section{Lusaka socio-economic context}

Lusaka city is a capital of Zambia which has today more than 1.5 million inhabitants (estimate from 2010). ${ }^{4} 80 \%$ of Lusaka's residents live in townships known as

4 Estimates from 2010 shows that total number of Lusaka inhabitants was 1,084,704.

DOI: 10.2478/eas-2018-0004 C University of SS. Cyril and Methodius in Trnava. All rights reserved. 
"compounds" which are low income housing and squatter settlements and $40 \%$ are officially unemployed (HANSEN 2008; MULENGA 2003).

The informal economy has been the most important source of livelihood in the city. It encompasses posts such as taxi drivers, street food vendors, art and cloths vendors, woodworkers, auto mechanics, domestic workers, and also healers. Many Lusaka dwellers practice the Multiple Modes of Livelihood which means they combine an income from both formal and informal economy.

Since the 1980s when the rate of unemployment in Lusaka has progressively increased, the rank of "self-employed" people emerged. This new socio-economic class composed of young men and women is characterised by the ability at economic improvisation and social negotiation, they employ diverse strategies to survive and safeguard their livelihoods. This class has become a symbol of new ways of conceptualisation of urban life pitfalls that according to Ferguson "value multiplicity, variation, improvisation, and opportunism and distrust to fixed, unitary modes of practice" (FERGUSON 1999:44).

Poverty as the most burning problem of modern Zambia has increased from 49\% in 1991 to $64.2 \%$ in 2007 whilst the largest incidence of poverty was recorded in the period between 1991-1998. According to the UN Human Development Report 2007, more than $60 \%$ of the population lived below the international poverty line ${ }^{6}$, while an additional 17.2 $\%$ were vulnerable to multiple deprivations such as access to education and health infrastructure. Among the major causes of actual poverty, the counterproductive policies of Kenneth Kaunda's regime (1964-1991), the high population growth, a one-sided oriented economy and the negative impact of the IMF/World Bank Initiated Structural Adjustment Program (SAP) in the $1990^{\prime} \mathrm{s}^{7}$ are often cited.

5 The term derives from the urban-control apparatus that during the colonial period invoked race to segregate housing, labour, health, and domestic arrangements. Compound, a term common throughout the southern African region, first came into use for the housing institution adopted on the gold and diamond mines in South Africa in the late 1980s. In postcolonial Zambia, the semantic field of the term has come to encompass all low-income areas (HANSEN 2005).

$6 \quad$ International poverty line was 1.25 US dollars per day (UN Human Development Report 2007).

$7 \quad$ The increasing economic crisis of the late 1980s led to the implementation of the Structural Adjustment Programme (SAP) in the 1990s comprising reforms such as the privatisation of the copper industry, exchange rate liberalization, tax reforms, removal of subsidies, control of agriculture prices, privatization of agriculture, introduction of user fees for health and education. 
At the time of my research, Zambia occupied a low position on the scale of Countries Human Development Index, namely 164th out of 187 countries (2009). In comparison with its position today (141/187 in 2013), we can conclude that national economic and living conditions of Zambians have significantly improved. At least in Lusaka, economic growth can be seen practically on every corner. Many new commercial buildings, shopping malls, banks, hotels, petrol stations are mushrooming in downtown, the quality of bus transport and infrastructure among the cities has visibly improved, even the living conditions in compounds have enhanced significantly. ${ }^{8}$ The development of national economy has meant that the formerly one sided economy which was oriented to the export of copper, has been advanced within the last five years by close trading partnerships with China, Brazil and India. However, the absence of a dynamic, fast-growing manufacturing sector which could create jobs is one of the challenges facing the economy.

The recent Labour Force Survey data (2014) showed that out of the 5.86 million people were employed in the country, from which $22.3 \%$ are paid employees; $28.1 \%$ are selfemployed and $48.6 \%$ are contributing family workers.

Since 2008 also the health sector has recorded progress in most of the key areas of healthcare service. The development of the health sector contributed to a rise in the average life expectancy at birth from 47 years (in 2008) to 52 years (in 2012). ${ }^{9}$ The vulnerability of economically disadvantaged such as divorced or widowed women and children, particularly orphans whose number due to the AIDS pandemic increases every year, is the most visible within the context of expanding human traffic. The International Labour Organisation (2008) describes Zambia as "hub" for human traffickers operating in southern Africa, whereas big urban centres such as Lusaka are the most afflicted in this respect. ${ }^{10}$ Lusaka is the transit point for the regional trafficking of women and children for the purposes of forced labour and sexual exploitation

These reforms however sparked violent protest in the Copperbelt and Lusaka (MULENGA CAMPENHOUT 2003).

8 According to my observation after having returned to Lusaka in March 2014.

9 UNDP 2010.

10 This is due to the fact that Zambia is in the geographic centre of the region and thus serves as a major battleground in the fight against the illegal movement of people, usually from countries like Mozambique and the Democratic Republic of Congo, who are abducted to South Africa and beyond. 
The high HIV/AIDS prevalence estimated at $16.5 \%$ of the total population in 2007 has decreased by more than $2 \%$ within the last five years, in Lusaka the percentage of HIV/AIDS is higher by $2 \%$. Among other common health problems, the TB, malaria, respirational and digestive problems prevailed. The biomedical treatment was not very popular among Zambians, not only because it is expensive or inaccessible (it is currently estimated that in urban areas $99 \%$ of households are within $5 \mathrm{~km}$ of a health facility) but because of incompatibility of biomedical and local cultural conception of illness. In the eyes of Lusaka dwellers, biomedicine is ineffective and incapable to deal with social and spiritual problems. As belief in spiritually caused illnesses such as spirit possession, or witchcraft pervades the mind of the majority of Zambians, the option of indigenous therapy or therapy in African Christian churches logically ensues.

African Independent Churches represent an extremely important structural component of Zambian society, especially in urban centres where they occur in large numbers. As many Zambians are strong believers, belonging to a church community is a fundamental part of their social and political life. Christian churches located in every Lusaka compound represent a space where strong feelings of being (locality and identity) belonging (kin, reciprocity, the others) and believing (morality, agency) are constructed (CHABAL 2009). Zambia has a particular make-up that gives the church a special importance from the socio-political point of view. "The manufacturing sector is controlled by expatriates most of whom are South Africans while the trading sector is dominated by Asians. In this sense the only sector opened to Zambians is politics, the civil service and the church" (GIFFORD 1998:220-221). As many Zambians living in the compounds lack the sufficient education and their social and economic capital is rather limited, the majority of them are also excluded from participating in politics or civil service. In this situation the sector of the African Independent Churches remains the main "socio-political field" where ordinary Zambians can gain social prestige and authority.

\section{Traditional healers' associations}

According to World Health Organisation statistics from 2001, at least $70 \%$ of Zambian population use traditional medicine. Unlike during the colonial period when traditional medicine was denigrated, after the Independence and particularly since the $1980 \mathrm{~s}$ it has been rehabilitated. At that time different traditional healers' associations were founded 
and partly supported by policies of national government. The largest national association of healers is Traditional Health Practitioners Association of Zambia (THAPAZ) with more than 40,000 members. There are other associations such as the Zambian National Council of Ng'angas (ZNCN), Zambian Herbalist United Organisation (ZHUO) and Zambian Institute of National Medicine and Research (ZINARE).

The main task of these associations is to register, control and review traditional healers in country at national and regional level, to promote traditional medicine as a cultural heritage and, above all, to offer safe, quality, accessible and cost-effective primary health care. Some of these associations also promote the research of phytopharmaceuticals and cooperate with the Ministry of Health. For example, Traditional Birth Attendants practise at the level of primary health care today. Some healers also participate in the national prevention HIV/AIDS program and cooperate with USAID and WHO.

Traditional medicine is, however, not integrated into the national health system and the treatment is not thus covered by the health insurance in Zambia. The average charge for the basic consultation of traditional healer ranges from 30-50 ZKW (Zambian kwachas). The charges for traditional chirurgical interventions range from 150-200 ZKW such as for example the mulumiko method based on sucking out the parasitic objects (viposo) such as teeth, claws, bones or even small animals circulating in the blood of the patients by means of a horn which is leeched onto the affected area where a ndembo (incision) has been done before. The most expensive are rituals of cleansing house off the magical objects laid by a witch provided by witch-finders in Lusaka that consists of the detection, neutralization and destruction of the magical objects called chinyanga in a patient's house, or several days lasting drumbeating ceremony ngoma organised by spiritual healers within the cults of afflictions. The costs covered by the patient with the help of his therapy management group ranged between 100,000 - 200,000 ZKW (i.e. 10,000 - 20,000 US dollars). The patient covers travel costs for all participants, drummers, food and drinks (especially a home-made beer and a kachasu home-made spirit), cigarettes, candles and a sacrificial animal (goat). The similar price went for the house cleansing ritual.

According to the Constitution of Traditional Health Practitioners Association of Zambia (THAPAZ), the Zambian traditional medico-religious system recognises five categories of healers: herbalists, diviners, spiritual healers, faith healers and birth attendants. Every traditional healer who runs his job should achieve the minimal level of education (primary school leaving certificate) and minimum age of 18 years. Zambian healers must be 
registered in the THAPAZ to gain the Competence Certificate (for foreign healers International Certificate) otherwise his activities are considered illegal. The Competence Certificate costs $100 \mathrm{ZKW}$ and it should be renewed every five years. Apart from the Competence Certificate, a healer must dispose a valid practicing permit and valid membership card of a given association. ${ }^{11}$

Every healer who is a member of THAPAZ must successfully undergo the attestation procedure to prove sufficient knowledge of traditional medicine and special required skills. The certified healer should be able to recognize at least 30 different herbs and to submit at least two medicaments prepared and used by him, so that it can be tested for efficacy (The Constitution of THAPAZ 2001).

There are several formal prohibitions issuing from the Constitution of THAPAZ violation of which is punished by a respective fine and healer's dismissal from the association. The following list of prohibitions linked to practicing witchcraft and witch-finding is given in descending order according to an appropriate amount of fine, i.e. seriousness of an offence:

- To point out someone as sorcerer, wizard or a witch without any facts or exhibits to stand in courts of law as a proof (50 000 ZKW)

- $\quad$ To help criminals by the use of charms and fetishes (50 $000 \mathrm{ZKW)}$

- $\quad$ To engage in black magic, the occult, sorcery, wizardry, witchcraft...to summon rituals which so performed will incapacitate, maim or in any way harm or kill a person, his family, livestock, live hood or business (25,000 ZKW)

- $\quad$ To practice hypnotism $(25,000 \mathrm{ZKW})$

- $\quad$ To wretch and destroy families by the use of charms and fetishes (15,000 ZKW)

- $\quad$ To wilfully and with knowledge prepare harmful medicine for a patient where a patient dies due to such negligence $(15,000 \mathrm{ZKW})$

11 Every member shall upon Admission pay a registration fee of 150 Zambian Kwacha. To obtain a membership card, the fee of 500 Zambian Kwacha is required. Every registered healer has to pay a fee of $300 \mathrm{ZKW}$ as an annual Renewal contribution. The Competence Certificate costs 100 ZKW, this shall be renewed every five years according to Clause 6: Admission Fee in the THPAZ Constitution 2001 (The prices are from year 2009). 
- $\quad$ To practice finding out the guilty by hot water and fire method $(10,000 \mathrm{ZKW})$

Other examples of official prohibitions targeting all categories of healers are given in a descending order according to an appropriate amount of fine:

- $\quad$ advertising a healer's service through the print and electronic media under the fine $(150,000 \mathrm{ZKW})$

- To seduce or commit adultery with the wife or husband of a colleague or a patient. $(100,000 \mathrm{ZKW})$

- $\quad$ Taming the tongue - gossiping, jealously and hatred $(15,000 \mathrm{ZKW})$

- $\quad$ To sexually imitate with patient $(50,000 \mathrm{ZKW})$

- $\quad$ To divulge the secret about the sickness of a patient $(25,000 \mathrm{ZKW})$

- $\quad$ To vend and sell herb or traditional medicine along the streets and open-air markets $(10,000 \mathrm{ZKW})$

- $\quad$ To expose his private parts, to be nude or improperly dressed (5,000 ZKW) (THAPAZ 2001)

In addition to official written restrictions in the Constitution of THAPAZ ${ }^{12}$, there are also several informal unwritten restrictions issuing from everyday practice of traditional healers. Firstly, the majority of healers consider a commercialisation of herbal medicine and its selling in the streets as an abject practice that infringes the taboo on pollution of herbal medicine.

"Soweto healers" are commercial (...) they are spoiling medicine, on the market you can see people aborted, menstruating, people that have just had sex... they go around the shrine, they touch exposed medicine and they spoil it. You cannot market medicine [medicinal herbs] like this. It is something sacred, you must keep it pure, otherwise the medicine like this would kill people" (Dr. Bongo, Lusaka).

12 The Constitution of Zambian National Council of Nga'ngas (ZNCN) contains the same restrictions.

13 Healers who sell herbal medicine at open-air market Soweto in Lusaka.

DOI: 10.2478/eas-2018-0004 C University of SS. Cyril and Methodius in Trnava. All rights reserved. 
Secondly, the majority of traditional healers emphasized the importance of the inalienability of healers' personal secret of preparation of traditional medicine. In their opinion, every healer in his own interest should treasure his secret of preparation of traditional medicine which he uses to cure his clients.

Thirdly, there is healers' unwritten convention not to denounce healer who practice witch-finding. This common practice points to shared solidarity within the community healers.

"Our friends [witch-finders] are powerful healers who do their good jobs. There are also those who kill enemies with magical spells. We must respect them. Dr. Kasanda whose grandfather was first and the most reputable witch-finder in Lusaka, is continuing this job. He helps people as we do...But not everybody can do that, it is very dangerous and if you are not good in it, you can die" (Dr. Kushita Solo, Lusaka).

Finally, traditional healers condemn bad and overpriced healing services of some healers in town and they consider these activities as illegal.

"Our friends [Soweto healers] want just money. Our friends are hungry; they are looking for customers. If you are a good healer, people will find you. Our parents never did it like this" (Dr. Kushita Solo, Lusaka).

\section{Characteristics of witch-finders}

Witch-finders are popularly called witch-doctors in English or mchape in chiNyanja ${ }^{14}$. Local people see them as the most powerful of all $n g$ 'angas (traditional healers) for their ability to fight with the dangerous magical forces used by witches. Being a witch-finder thus

14 Mchape or mcape is a chiNyanja, local variations of this term include mcapi, mucapi. Bembas call witch-finders the bamucapi. This word refers not only to a witch-finder but also to a special medicine used as an ordeal. When witch-finders detected witches, they gave them mchape medicine - a special non-poisonous medicine of red colour and soapy appearance - that served as a poison ordeal. It was believed that mchape would cause that any witch who returned to his evil practice to die (Marwick 1965). My informants defined mchape as "a medicine prepared by a witch-finder" which is given to patient to drink to prove whether he is a witch or not. It is believed that if a person drinks it, the spirit enters his body and makes him speak and explains what he has done wrong. 
means to have spiritual power, authority and social prestige. However, there is a strong ambivalence of the roles of witch, sorcerer and $n g$ 'anga. In this respect it needs to be stressed that in Lusaka, as in many other African societies, it is believed that a witchfinder, who possesses the same magical power as a witch, can manipulate it both positively and negatively. The fact that they both draw on the same occult power and use the same magical means to pursue their goals makes witch-finders highly ambivalent and redoubtable figures.

"A witch-finder has the same power as witches, because he manages to stop what they are doing and he uses the same medicine as they use. We are even stronger that those witches. We can give back life to someone who had finished [died as a result of being bewitched]. If we manage to do this it simply means that we are chiefs of all witches" (Dr. Mukanda, Lusaka).

Most witch-finders I met in Lusaka were men between 30 and 40 years of age who had continued witch-finding tradition within the family. They either inherited the power to fight witchcraft through the spirit of their dead father who was a witch-finder too, or they got possessed by different traditional or Christian spirits used for witch-finding.

A detection of witches and healing of those being bewitched is the main form of their subsistence. Their income is variable and depends on number of clients, social capital and even on season. For example, in rainy season they have plenty clients because people stay close to each other at home and quarrel often, but in dry season they do not have enough clients and sell magical objects to museums to gain money.

Their occupation is not merely a means of subsistence but it is conceived as a whole-life mission. The healers are considered as chosen by supreme powers - either ancestral spirit or biblical figures to carry out their work. The majority of them affirmed an initial resistance and defiance to "spiritual calling" and claimed to become healers against their will. As Dr. Mukanda stated: "I am not happy to become a ng'anga, I always wanted to have a normal job, to be a carpenter." 
Lusaka's witch-finders are typical creative and experimental figures, a sort of "bricoleur" (handymen) in Lévi-Strauss sense (1966) ${ }^{15}$. They are able to appropriate and redeploy the terms, ideas and symbols from Christianity, medical science, the commodity market and other areas and to construct new comprehensible arrangements for a patient. The healer's ability to introduce innovations in their "art of healing" conforms to, on one hand, the demand of clients, on the other, it represents the way how "everyday experience is recasting prior meanings as it confronts new signifiers themselves variously empowered" (COMAROFF - COMAROFF 1993:22).

Many traditional healers I met appropriated symbols of western medicine such as a white coat, a book of patients or herbal medicine dosages. The medicalisation of traditional healing has been manifested even in the language the healers used. They call themselves doctors, or researchers and their consulting room is called a surgery or clinic. They used the expression 'vaccination' when talking about traditional chirurgical healing method known under the name 'tattoos' or ndembo.

\section{Tactics of witch-finders in "getting their place in the sun"}

Lusaka's witch-finders have developed and employed several tactics to keep their "illegal" job in secrecy and anonymity and at the same time to actively negotiate their legitimacy in town. They scarcely advertise their services publicly and their consulting rooms are well hidden deeply in Lusaka's compounds. The place where they work and the place where they live are usually not in the same compound. I know from my own experience that their consultation rooms are not easily accessible by public transport. One must walk deep into compound, being lost in labyrinth of identical streets without names, wandering for a long time before reaching the place of destination. Moreover, even people from close neighbourhood do not know about a consultation room of a witch-finder, or possibly they

15 Claude Lévi-Strauss's (1966) notion 'the bricolage' refers to the nature of reasoning of the archaic societies. The archaic man is compared to a bricoleur who creates improvised structures by appropriating pre-existing materials which are ready-to-hand (LÉVI-STRAUSS 1966:16-33). The bricoleur works with signs, "constructing new arrangements by adopting existing signifies as signifiers and speaking through the medium of things" - by the choices made from "limited possibilities' (LÉVI-STRAUSS 1966:20-21).

DOI: 10.2478/eas-2018-0004 @ University of SS. Cyril and Methodius in Trnava. All rights reserved. 
do not have trust in muzungu ofunta - a "crazy European" searching for a witch-finder there.

For not being suspected of breaking the law, witch-finders never explicitly mention the name of an alleged witch during the divination séances. They know the fact that the Witchcraft Act (1995) forbids: "witch-finding activities and sets the 'penalty for naming, accusing or imputing witchcraft ${ }^{16}$ and the 'penalty on the professional witchdoctors and witch-finders". 17

During the divination séance a witch-finder draws a patient, who is generally not well acquainted with the field of knowledge about witchcraft, into the "construction of his story" by means of impressive and nightmarish witchcraft symbols figuring in detailed description of the technics used by a witch. They draw on the rich symbolism which enables them to easily manipulate a patient's view and convince him of the veracity of the final diagnosis. To avoid pointing out someone as a witch, witch-finders only specify the place where alleged witch lives and mention his/her position within the family. Such enunciation during the divination séance might stand as:

"Those who eat you [witches] are not from your house, they live far away... those witches come from your husband's side. I can't see their faces, they hide them in white masks" (Dr. Kasanda, Lusaka).

Another witch-finders' tactic how to hide their illegal activity is to rely on the network of their loyal clients and gain new clients mostly by the method of a snowball. This means that they accept new clients just on recommendation of their former or actual patients or they accept those coming from another witch-finder they know well. To ensure enough new patients, they search for clientele outside the city, particularly in villages.

Their inaccessibility, as it has been mentioned above, is also expressed by travel mode they embody. They are always on the road, travelling all around the country and even

16 The penalty for naming, accusing or imputing witchcraft is: “( ...) the fine not exceeding 750 penalty units or to imprisonment with or without hard labour for any term not exceeding one year, or to both" (Penal Code 1995, chapter 90, article 4; Appendix II, 12).

17 The penalty on the professional witchdoctors and witch-finders is: "(...) under the fine of not more than one thousand five hundred penalty units or imprisonment with or without hard labour for any term not exceeding two years" (Penal Code 1995, chapter 90, article 4; Appendix II, 12).

DOI: 10.2478/eas-2018-0004 C University of SS. Cyril and Methodius in Trnava. All rights reserved. 
abroad. They are "here and there" and similarly as witches they are hardly catchable in case of random official controls from THAPAZ.

By travelling they also ensure material and intellectual sources for their future successful work and enforce their position amongst other healers in town. Since their legitimacy is threatened by many "official" healers in the city, it must be constantly negotiated by introducing innovations. The ability to keep clients and to gain a good reputation depends on the originality of their diagnostic and therapeutic procedures. As they travel and meet other witch-finders, they gain new herbs, new ideas, new "tricki", i.e. tricks how to convict clients of being an excellent healer. To give an example of the innovation, let me cite a witch-finder who expressed his doubts about using the most common divinatory techniques of mirrors which have been now substituted by the method of witchcraft detection by means of spirit of a dead person.

"You have to be innovative, because witches are very clever. They use the same mirrors as we witch-finders. If they want, they can break the mirrors of mchapi [witch-finders]. I saw many mchapi coming to the village with their mirrors to cleanse the villagers, all failed. Then, I went there and I could stop them [witches] because I used a spirit. The witches cannot destroy someone who is dead (...) it is not possible to kill the ghost, it is like to trying to kill the death ... [laughing]" (Dr. Mukanda, Lusaka).

Witch-finders are also forced to diversify their professional competences to withstand competition in town. For example, they extend their traditional offer of service in the way that they do not only provide searching for witches but also for robbers, run-away husbands etc.

To survive in the city, particularly in a "hungry season" when they do not have enough clients, some of them cooperate with local trials. They attend the witchcraft accusation law cases at local trials as expert consultants. They exhibit a direct divination during the session, or expose confiscated magical objects to the court as corpus delicti. Others sell their confiscated magical objects to museums in Choma or Livingstone.

Another tactic how to legitimate and confirm their spiritual authority vis-à-vis their clients is to use the symbols of healing in a form of exposed paraphernalia in a consulting room. The exposed paraphernalia in front of the patient make him trust in the authority of the spirits the healer "works through" or "works with". It represents evocative memorials of the diviner's personal history, wisdom and knowledge accumulated both in the history of 
the family as well as during his life. It thus confirms his spiritual authority and power in the eyes of his patients.

\section{Conclusion}

To work as a "full time" witch-finder in Lusaka necessitates a constant negotiation of their legitimacy. The position of witch-finders is challenged on one hand by increasing competition of other healers in the city as well as by demonization campaign led by African Independent Churches and the media. To become a successful witch-finder it necessitates to develop a range of effective tactics how to attract clients and get rid of the danger to be revealed. The question might stand, how is it possible that in such competitive environment other legitimate healers do not try to denounce witch-finders to draw more clients? The answer is very prosaic. The healers are afraid that mchapes might bewitch them so they rather tolerate them.

The credibility of witch-finders in Lusaka depends also on their good reputation among patients and other healers. A reputable witch-finder builds on charismatic personal quality, rich social capital and clientele and particularly on the quality of healing competences acquired in the process of long apprenticeship and measure of successful therapy results.

\section{Acknowledgments}

This article results from the paper presented at the ECAS 2017- 7th European Conference on African Studies in Basel 29 June - 1 July 2017. The paper with a title "Strategies and negotiations of legitimacy of witch-finders in Lusaka-city" was presented in the panel P092: Contemporary politics of informality: encounters between the "formal" and “informal" African city on Friday 30 June, 16:00 - 17:30, Location: KH103.

This work was also supported by MŠMT, grant IGA_FF_2017_IGA_FF_2017_015: Integrovaný sociálně vědní výzkum (KSA 2017). 


\section{Bibliography}

CHABAL, P. (2009): Africa. The Politics of Suffering and Smiling. South Africa: University of KwaZulu Natal Press.

COMAROFF J. - COMAROFF J. (1993): Introduction. In: Comaroff, J. - Comaroff, J. (eds.) Modernity and Its Malcontents. Ritual and Power in the Postcolonial Africa. Chicago: University of Chicago Press, 1-25.

DILLON-MALONE, C. (1988): "Mutumwa Nchimi Healers and Wizardry Beliefs in Zambia”. Social Science and Medicine 26, No 11, 1159-1172.

FERGUSON, J. (1999): Global Disconnect. Abjection and the Aftermath of Modernism. Unpublished paper.

FRANKEBERG, R. (1969): "Man, Society and Health: Towards the Definition of the Role of Sociology in the Development of Zambian Medicine". African Social Research 8, 573-587.

FRANKEBERG, R. - LEESON, J. (1977): "The Patients of Traditional Doctors in Lusaka". African Social Research 23, 217-234.

HANSEN, T. K. (2008): The Informalisation of Lusaka's Economy: Regime Change, Ultra Modern Markets and Street Vending, 1972-2004. In: Gewald, J. B. - Hinefelaar, M. - Macola, G. (eds.) One Zambia, Many Histories. Leiden: Brill.

JULES-ROSETTE, B. (1981): Symbols of Change. Urban Transition in Urban Community. London: Ablex.

LAST, M. - CHAVUNDUKA, G. L. (1986): The Professionalization of African Medicine. Manchester: Manchester University Press and International African Institute.

LÉVI-STRAUSS, C. (1966): The Savage Mind. Chicago: University of Chicago Press.

MARWICK, M. G. (1965): Sorcery in its Social Setting: A Study of the Northern Rhodesian Chewa. Manchester: Manchester University Press.

MILDNEROVÁ, K. (2015): From Where Does the Bad Wind Blow? Spiritual Healing and Witchcraft in Lusaka. Berlin: Lit Verlag.

MULENGA, L. CH. (2003): Urban Slums Report: The Case of Zambia, Lusaka. In: Understanding Slums: Case Studies for the Global Report 2003. Lusaka.

MULENGA, S. - CAMPENHOUT, B. van (2003): Decomposing Poverty Change in Zambia. Growth, Inequality and Population Dynamics. African Development Review 20 , No. 2, 284-303. 
MUUKA, N. G. (1997): "Too Rich to Be Poor? A Glimpse of the Poverty Situation in Zambia in the 1990s." Scandinavian Journal of Development Alternatives and Are studies 16, No. 1, 139-156.

SUGISHITA, K. (2009): "Traditional Medicine, Biomedicine and Christianity in Modern Zambia”. In: Africa. International African Institute 79, No. 3, 435-454.

\section{Other sources}

Central Statistical Office. 2009. Living Conditions, Poverty in Zambia 1991 - 2006. Lusaka: CSO.

Central Statistical Office. 1994. The Social Dimensions of Adjustment Priority Survey I. Lusaka: CSO.

International Labour Office. 2008. Investigation Forced Labour and Trafficking in Zambia. Lusaka: International Labour Office.

International Labour Office. 2014. Labour Force Survey data. Lusaka: International Labour Office.

Republic of Zambia. 1995. Witchcraft Act. In: Penal Code, Chapter 90. Lusaka: Government Printers.

Traditional Health Practitioners Association of Zambia. 2001. Constitution. Code of ethics. Policy Guidelines. Lusaka: THAPAZ.

United Nations Development Programme. 2010. Human Development Report 2010. New York: UNDP.

World Health Organisation. 2001. Legal status of traditional medicine and complementary/alternative medicine. A worldwide review. Geneva: WHO. 